\title{
Empowering women beyond Finland
}

Written by: OECD

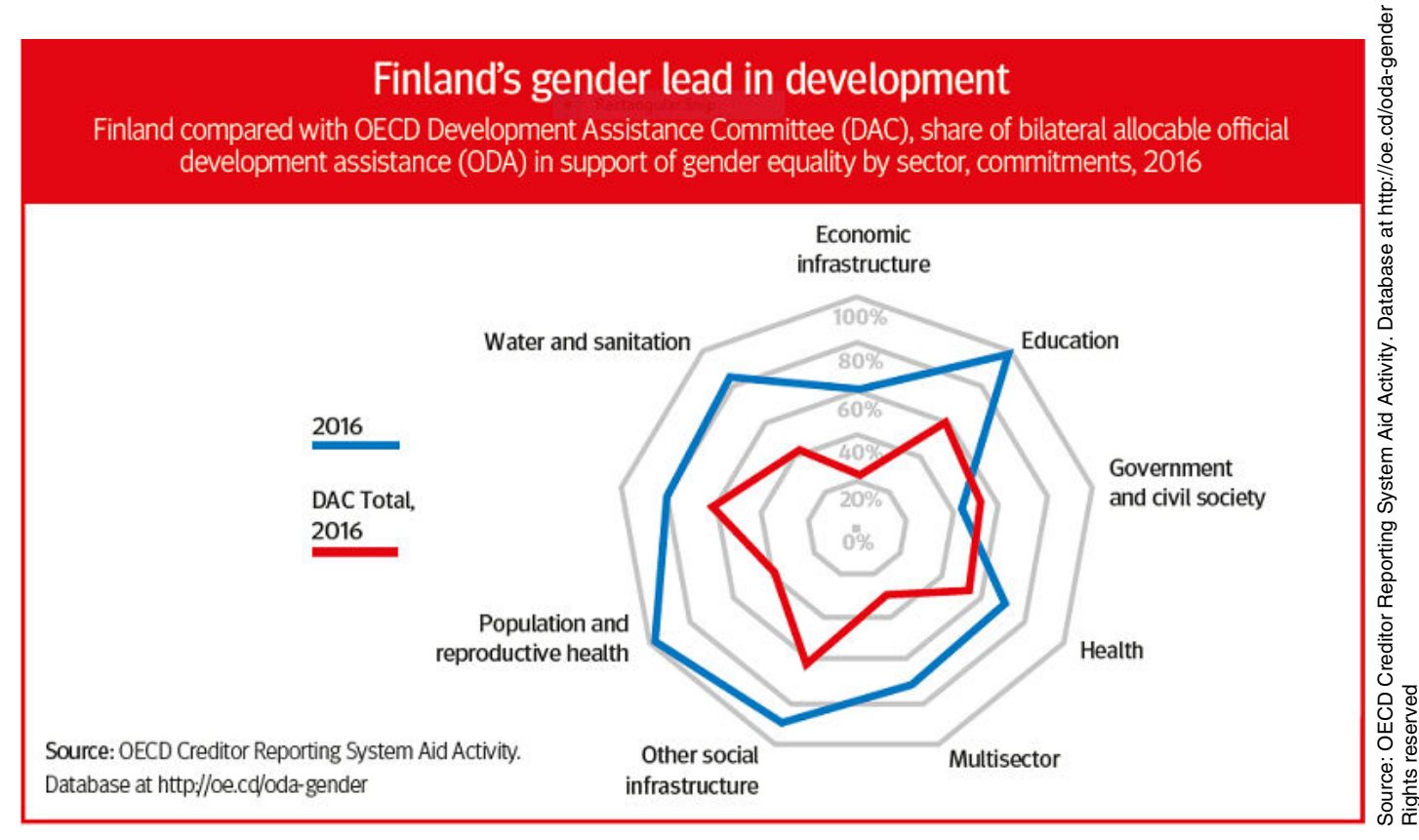

Empowering women beyond Finland

\section{From introducing equal inheritance rights in 1878, Finland continues to earn it's reputation as a global pioneer of gender equality.}

Finland's global reputation as a gender-equality pioneer is well earned. It introduced equal inheritance rights in 1878, gave women the right to study at university in 1901 and the right to vote in 1906. It should be no surprise, therefore, that the rights and status of women and girls should be a priority in Finland's development co-operation policies as well. This is reflected in the country's strong support of multilateral organisations with a mandate to work on women's empowerment and sexual and reproductive health and rights.

In 2002, Finland was among the OECD Development Assistance Committee (DAC) countries-together these countries account for some $90 \%$ of total bilateral official development assistance-to spearhead reporting on gender equality as part of its development work. Finland's share of gender-focused bilateral aid reached 53.2\% 
in 2016 , well above the DAC average of $36.5 \%$. Over $80 \%$ of Finland's ODA investments in education, water and sanitation focus on gender equality.

Finland actively supports countries in developing their own national plans for implementing United Nations Security Council Resolution 1325 on women, peace and security. To ensure that civilian and military experts deployed in crisis management operations respect gender, Finland has developed a gender checklist used by the Finnish Defence Forces International Centre.

This Databank is part of a series of articles celebrating Finland's 50th anniversary as a member country of the OECD: www.oecdobserver.org/finland50oecd COECD Observer January 2019 